\title{
Introducing the Moniac: Its Historical Process in the Istanbul University Faculty of Economics
}

\author{
Milli Gelir Hesaplama Makinesi (Moniac): İstanbul Üniversitesi \\ İktisat Fakültesi'ndeki Tarihsel Süreci
}

\author{
Nazan SUSAM ${ }^{1}$ (D) Nurtaç YILDIRIM² $^{2}$, Hakan BEKTAŞ ${ }^{3}$ (D)
}

\begin{abstract}
Monetary National Income Analog Computer (MONIAC) is a hydraulic machine that we can describe as an analog simulator modeling macroeconomic relationships. It was invented by the famous economist A. W. Phillips in 1949 and produced in limited numbers. The circulation of water in the machine shows the circulation of money in the economy. The economic behaviors of units such as households, firms, government, export, and import segments, and the economic variables by which these behaviors are affected can be observed while the water circulates the machine. The working principle of this machine reflects the assumptions of both Keynesian and Classical economics schools regarding economic functioning. The machine was brought to Istanbul University Faculty of Economics in the 1950s, by Prof. Dr. Besim Ustunel, one of the late faculty members. A sensational scientific production for the international academic community at that time, thus, was brought to Turkey in a very short period of time. The fact that the machine was introduced to Turkish higher education shortly after its invention is an important indicator of the ability of the Faculty of Economics to adapt to current scientific developments. Although MONIAC has been reoperational with a project initiated by the Faculty of Economics in 2017, it is not possible to use the machine actively in lessons today, which used to be one of its primary functions. However, based on this analog machine, the digital simulation that we carry out within the scope of the project can be used as an educational tool. MONIAC, in its restored original form, has been preserved by the Faculty of Economics as a historical value of the Faculty.
\end{abstract}

Keywords: National income calculator, MONIAC, W. Phillips machine, Circular flow of income

JEL Classification: A20, E01, E50, E60, F41

\section{Öz}

Parasal Milli Gelir Analog Bilgisayarı (MONIAC), makro ekonomik ilişkileri modelleyen bir analog simülatör olarak tanımlayabileceğimiz hidrolik bir makinedir. Ünlü iktisatçı A.W. Phillips tarafından 1949'da icat edilmiş ve sınırlı sayıda üretilmiştir. Makinede su sirkülasyonu, ekonomideki paranın dolaşımını
'Prof. Dr., Istanbul University, Faculty of Economics, Department of Public Finance, Istanbul, Turkey

${ }^{2}$ Assoc. Prof. Dr., Istanbul University, Faculty of Economics, Department of Economics, Istanbul, Turkey

${ }^{3}$ Assoc. Prof. Dr., Istanbul University, Faculty of Economics, Department of Econometrics, Istanbul, Turkey

ORCID: N.S. 0000-0003-4078-3217; N.Y. 0000-0002-4374-2958; H.B. $0000-0002-7856-2674$

Corresponding author/Sorumlu yazar: Hakan BEKTAS

Istanbul University, Faculty of Economics, Department of Econometrics, Istanbul, Turkey E-mail/E-posta: hbektas@istanbul.edu.tr

Submitted/Başvuru: 28.05.2021 Accepted/Kabul: 30.05 .2021

Citation/Atıf: Susam, N., Yildirim, N., \& Bektas, $\mathrm{H}$. Introducing the Moniac: Its historical process in the Istanbul University Faculty of Economics. Istanbul Iktisat Dergisi - Istanbul Journal of Economics, 71(1), 1-19. https://doi.org/10.26650/ISTJECON2021-944190 
gösterir. Su makineyi dolaştırırken hanehalkı, firmalar, devlet, ihracat ve ithalat segmentleri gibi birimlerin ekonomik davranışları ve bu davranışların etkilediği ekonomik değişkenler gözlemlenebilmektedir. Bu makinenin çalışma prensibi hem Keynesyen hem de Klasik iktisat okullarının ekonomik işleyişle ilgili varsayımlarını yansıtmaktadır. Makine 1950'li yıllarda, emekli öğretim üyelerinden Prof. Dr. Besim Üstünel tarafından İstanbul Üniversitesi İktisat Fakültesi'ne getirildi. O dönemde uluslararası akademik camiada sansasyonel bir bilimsel üretim olan makine, böylelikle çok kısa sürede Türkiye'ye getirilmiş oldu. Makinenin icadından çok kısa bir süre sonra Türk yüksek öğrenimine dahil edilmesi, İktisat Fakültesi'nin güncel bilimsel gelişmelere uyum sağlama yeteneğinin önemli bir göstergesidir. MONIAC, İktisat Fakültesi tarafından 2017 yılında başlatılan bir proje ile yeniden faaliyete geçmesine rağmen, eskiden temel işlevlerinden biri olan derslerde aktif kullanımı mümkün değildir. Ancak bu analog makineden yola çıkarak proje kapsamında gerçekleştirdiğimiz dijital simülasyon bir eğitim aracı olarak kullanılabilmektedir. MONIAC, restore edilmiş orijinal haliyle, İktisat Fakültesi'nin tarihi bir değeri olarak fakülte tarafından korunmaktadır.

Anahtar kelimeler: Milli geliri hesaplayıCıSı, MONIAC, W. Phillips makinesi, Döngüsel gelir akışı

JEL Sınıflandırması: A20, E01, E50, E60, F41 


\section{Introduction}

Monetary National Income Analog Computer (MONIAC), which models domestic cash flow, was invented in 1949 by New Zealander engineer and economist W. (Bill) Phillips. Prof. Dr. Besim Üstünel encountered this machine during his Ph.D. studies at London School of Economics (LSE) and ensured that a sample of the machine would be brought to the Istanbul University Faculty of Economics with the support of the faculty dean of the period. The fact that the machine was introduced to Turkish higher education shortly after its invention is an important indicator of the ability of the Faculty of Economics to adapt to current scientific developments. Beyond being a course material, MONIAC has a remarkable scientific value. The machine, which aims to explain economic phenomena under a mechanical model, is a work that embodies the intersection of social and technical sciences. The machine, which served as active course material for a while in the Faculty, was later broken down and removed to the Faculty warehouses. Making the machine operational again is of great value not only for economics education but also for the history of science. Within this context, along with the sponsorship by Turkey Is Bank and Istanbul University Scientific Research Projects Support Unit, the Faculty of Economics started a project to make it work. In 2018, MONIAC was repaired and made operational by the expert physicist Adem Soylamış at Istanbul University. This study has been prepared for the promotion of the MONIAC machine as an output of the project carried out to make the machine work again.

\section{Phillips and Monetary National Income Analogue Computer (MONIAC)}

Alban William Housego "A. W." "Bill" Phillips was born in New Zealand in 1914 to a farming family. His father was just as talented as he was and invented many electric tools used on the farm. The Phillips family expanded their farm activities in the 1920s and increased production with new dairy farming methods. However, the stagnation experienced during the Great Depression in 1929 caused a fall in prices, and that also affected the agricultural production of the family. Although 


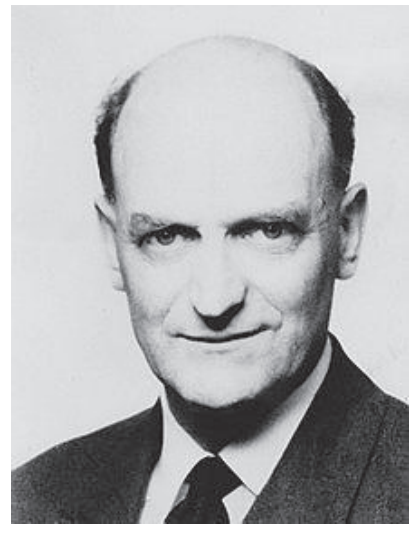

Phillips was a talented child, the family's lack of economic power to educate their children after the crisis crushed his dreams of enrolling in a college. Later, he managed to enroll in engineering courses with various difficulties. The fact that he encountered differential equations led to the development of his intellectual perspective. In 1937, due to the deterioration of the international political environment in the Far East, he decided to go to England, and his journey, which started on a Japanese ship, continued along the Siberian train line. Phillips, who found a job as an electrical engineer after settling down in England, also continued his education in electrical engineering (Bollard, 2011).

With the break out of World War II, Phillips joined the British Air Force (RAFRoyal Air Force) and was sent to Singapore as a flight lieutenant. Undertaking the maintenance of the old aircraft of the British air force, Phillips developed a method for the use of American heavy machine guns in that aircraft. When Singapore fell, he escaped to Java, and stayed there until Java was also invaded. Then, Phillips was captured by Japanese forces and spent three and a half years in a prison camp as a prisoner of war. He quickly put his inventive skills to use in the camp, building a miniature radio hidden in a clog and creating an immersion element, which ran from the camp lighting, to boil water for hot drinks ( $\mathrm{Ng} \&$ Wright, 2007, p. 46).

At the end of the war, he was sent back to his family in New Zealand in 1945 and awarded a New Zealand Forces scholarship, with which he attended LSE, studying first sociology and then economics (Ng \& Wright, 2007, p. 46). Phillips started to take an interest in Keynesian theory in the economics courses he took at LSE and tried to combine the theories and policies he learned with his engineering knowledge.

In early 1949, when Bill was in the final year of his degree at LSE, he met Walter Newlyn and showed Walter his drawings for a hydraulic machine that would 
model an economy. With a $£ 100$ grant from Leeds Head of Economics Arthur Brown, they took full advantage of both Bill's engineering skills and Walter's understanding of economic theory to build the machine during the summer holidays. At the end of this working process, MONIAC also known as the Phillips Machine, which is a hydro-mechanical machine modeling domestic cash flow, was invented by A.W. Phillips in 1949.

The acronym for MONIAC was formed to evoke the ENIAC digital computer that was later developed in the USA. Unlike these machines, MONIAC was operating on analog principles. About 14 of these machines were built, which are cited as the world's first econometric computer. The MONIAC used water to model flows of money in a macroeconomic system. The linkages were based on both Keynesian and Classical economic principles, with various tanks representing households, businesses, government, exporting, and importing

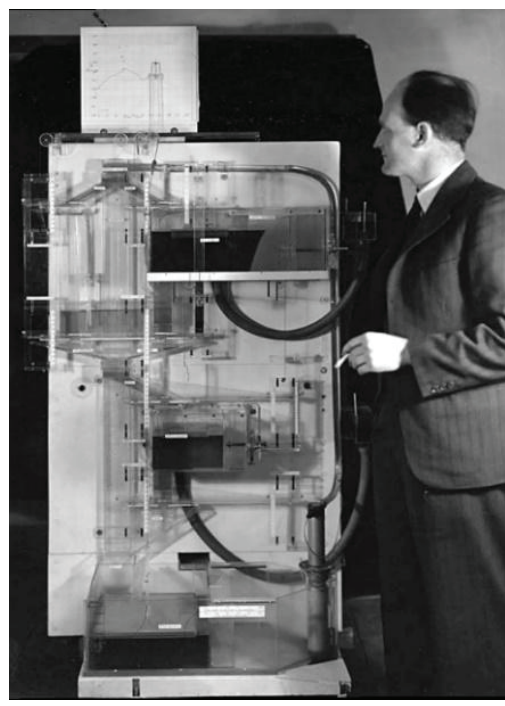
sectors of the economy. Water pumped around the system could be measured as income, spending, and Gross Domestic Product (GDP). The system was programmable, and experiments with fiscal policy, monetary policy, and exchange rates could be easily carried out (Ng \& Wright, 2007, p. 46; NZIER, 2016).

After Phillips designed and built the MONIAC hydraulic economics computer in 1949, he spent most of his academic career as a professor of economics at LSE. One of his best-known contributions to economic analysis is the Phillips curve, which he described first in 1958 (Barr, 2000). Within the Phillips curve analysis, he examined the relationship between the level of change of unemployment and the current change of wage rates. The analysis, which later became the trade-off between inflation and unemployment, produces a prediction relationship rather than a structural relationship. However, it has been the focus of discussions 
between Keynesian and Monetarist economists and remains one of the main issues currently being studied.

When we look at the macroeconomic implications of Phillips' hydraulic machine, it is seen that he thought and designed the macroeconomy to be a viable field. Indeed, he aimed to show how the monetary and fiscal policies used by the policymakers affect the targets related to macroeconomic variables. Phillips curve analysis also offered a policy option to the policymaker by showing the trade-offs contained in the policy tools it uses. Similarly, the hydraulic system emerged as an important visual design relating changing macroeconomic variables with the effect of monetary and fiscal policies on national income and economic growth.

In 1967, Phillips moved to Australia and took up a position in Australian National University. He suffered a stroke two years later and returned to New Zealand, where he taught at the University of Auckland. Phillips died in March 1975 (Ng \& Wright, 2007, p. 49).

\section{Working Principle of MONIAC}

The working principle of MONIAC is basically designed according to the simple Keynesian model with income-expenditure flow. If the national income is defined as the monetary value of the flow of goods and services produced in a country, measuring this value is important to be able to monitor the growth rate in a country, the change in living standards, the change in income distribution among different groups of the society and to compare all these with other countries in the world.

MONIAC is thought to be the hydro-mechanical model of the macroeconomy and has been designed as a national income calculator representing the income and expenditure flow. Rather than a perfect calculation, the machine clearly shows how the variables that make up the national income balance act depending on what factors and how a change in a variable affects the functioning of the economy. 


\subsection{National Income Equivalence Based on MONIAC Working Principle}

The equivalence used when calculating national income by expenditure also gives aggregate demand (AD) for goods and services.

$$
A D=C+I+C+(E x-I m)
$$

All expenditure items in the equation and the economic units making these expenditure decisions can be shown in the income-expenditure flow. Considering two main actors of the economy as firms and households; firms buy labor and other factors of production from households in order to produce; households receive income in the form of wages, interest, profit, rent in exchange for their participation in production; and then they spend their income on goods and services produced by firms. Thus, an income flow occurs from firms to households and from households to firms. In real life, the functioning of the economy is not that simple. All income is not captured in this stream; some of it flows out of the internal stream. At the same time, there are external contributions to the internal flow. To demonstrate this, the economic activity of households other than consumption, that is, the saving behavior of other units such as the government and the outside world that buys goods and services produced in the economy, are also included in the analysis.

Figure 1. The Circular Flow of Income

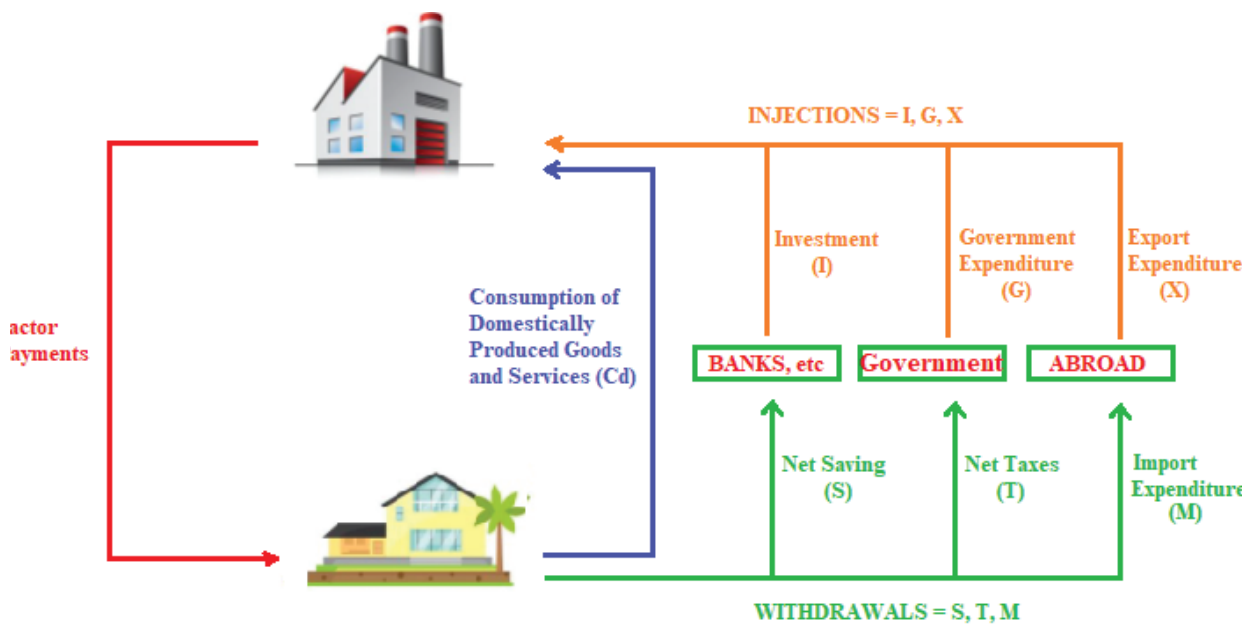


As seen in Figure 1, in the income-expenditure flow with the government, the rest of the world, and the financial system, some of the income obtained by households will be spent on the purchase of domestic goods and services while the rest will leak out of the flow. These leakages come in three forms: savings, taxes, and imports. Savings are transferred to financial institutions such as banks. The money thus flows from households to banks. When households pay taxes, money again leaks out of the domestic flow. This leakage passes into the government collecting the tax. Households do not spend all their income on domestically produced goods and services, they spend some of their income on imported goods and services. Not only households but also firms and the government spend on imported goods and services. This type of spending constitutes the third leakage from the domestic flow, in other words from the economy. All these leakages come back as "contributions" to the economy. Since there are three types of leakages, there are also three types of contributions: investment, public expenditures, and exports. The money leaking from the economy as savings and received by financial institutions is given to firms as loans. Firms, on the other hand, make investment expenditures with this loan, and the leakage is included in the economy again. Money leaking out of the incomeexpenditure flow as taxes, that is, from the economy, is reintroduced into the economy through public expenditures. Money leaking out of the income and expenditure flow as imports rejoins the economy as exports.

Table 1: Basic Macroeconomic Relationships

\begin{tabular}{|l|c|c|c|}
\hline Variable & Abbreviation & \multicolumn{2}{|c|}{ Equation } \\
\hline Income & $\mathrm{Y}$ & $\mathrm{Y}=\mathrm{C}+\mathrm{I}+\mathrm{G}+(\mathrm{Ex}-\mathrm{Im})$ & \\
\hline Taxation & $\mathrm{T}$ & $\mathrm{T}=\mathrm{T}(\mathrm{Y})$ & $\mathrm{T}=\mathrm{t}_{1} . \mathrm{Y} 0<\mathrm{t}_{1}<1$ \\
\hline Income After Taxes & $\mathrm{IAT}$ & $\mathrm{IAT}=\mathrm{Y}-\mathrm{T}$ & $\mathrm{IAT}=\left(1-\mathrm{t}_{1}\right) . \mathrm{Y}$ \\
\hline Consumption & $\mathrm{C}$ & $\mathrm{C}=\mathrm{C}_{1}(\mathrm{IAT})-\mathrm{f}_{\mathrm{c}}\left(\mathrm{i}_{1}\right)$ & \\
\hline Saving & $\mathrm{S}$ & $\mathrm{IAT}-\mathrm{C}$ & $\mathrm{S}=\left(1-\mathrm{C}_{1}\right) I A T+\mathrm{f}_{\mathrm{s}}\left(\mathrm{i}_{1}\right)$ \\
\hline Investment & $\mathrm{I}$ & $\mathrm{I}_{1} \mathrm{M}_{1}-\mathrm{f}_{\text {inv }}\left(\mathrm{i}_{1}\right)$ & \\
\hline Government Spending & $\mathrm{G}$ & $\mathrm{G}=\mathrm{G}(\mathrm{Y})$ & \\
\hline Government Saving & $\mathrm{GSV}$ & $\mathrm{T}-\mathrm{G}$ & \\
\hline Domestic Expenditure & $\mathrm{DE}$ & $\mathrm{C}+\mathrm{I}+\mathrm{G}$ & \\
\hline Gross Domestic Product & $\mathrm{GDP}$ & $\mathrm{DE}-\mathrm{IM}+\mathrm{NX}$ & $\mathrm{NX}=\mathrm{Ex}-\mathrm{Im}$ \\
\hline Export & $\mathrm{Ex}$ & $\mathrm{Ex}=\mathrm{Ex} \mathrm{x}_{0}$ & \\
\hline Import & $\mathrm{Im}$ & $\mathrm{Im}=I \mathrm{~m}_{0}+\mathrm{mY}$ & $0<\mathrm{m}<1$ \\
\hline
\end{tabular}


The economic functioning expressed by all these variables is explained on MONIAC with total demand items, $Y=C+I+C+(E x-I m)$. The variables are based on the inferences of Keynesian and Classical economics principles. In this sense, the analysis also reflects the features of a process in which American economists ceased to stand against or alongside Keynes towards the mid-1950s, and instead devoted themselves to neo-classical synthesis, which generally accepted the coexistence of neo-classical microeconomics and Keynesian macroeconomics. Indeed, the consumption and saving variables of the Keynesian school, which differ only depending on income, also vary depending on the interest rate in the neo-classical synthesis. Similarly, the investment variable, which is under the influence of Keynes' animal spirit and herding behavior, also depends heavily on interest rates in the neo-classical synthesis interpretation. In Phillips' system, what determines the interest rate is both investment and saving, referring to loanable funds theory of Classical economics, that is, the real sector, and the money market with reference to Keynesian analysis.

\subsection{Working Mechanism of MONIAC}

The functioning of the economy is designed on MONIAC as a process in which the water entering the system expressed as cash is pumped through hard plastic tanks and tubes. When the machine is started, colored water, which was the case in the original version, reaches the tanks through transparent pipes. The different water tanks on the machine show the household, firms, government, export, and import segments of the economy. The economic decisions and activities of these units are expressed as leakages from the income and expenditure flow and contributions to the flow represented by the circulation of water.

The rollers and adjustable metal extensions on the machine help regulate the water level and flow, and make it possible to include the exchange, interest, and tax rates into the system. Thus, how the variables that make up the national income balance are affected by a small change in income, interest, tax, and exchange rates and how they change the economic functioning can be monitored on the machine. 
Figure 2. Operation Mechanism of MONIAC

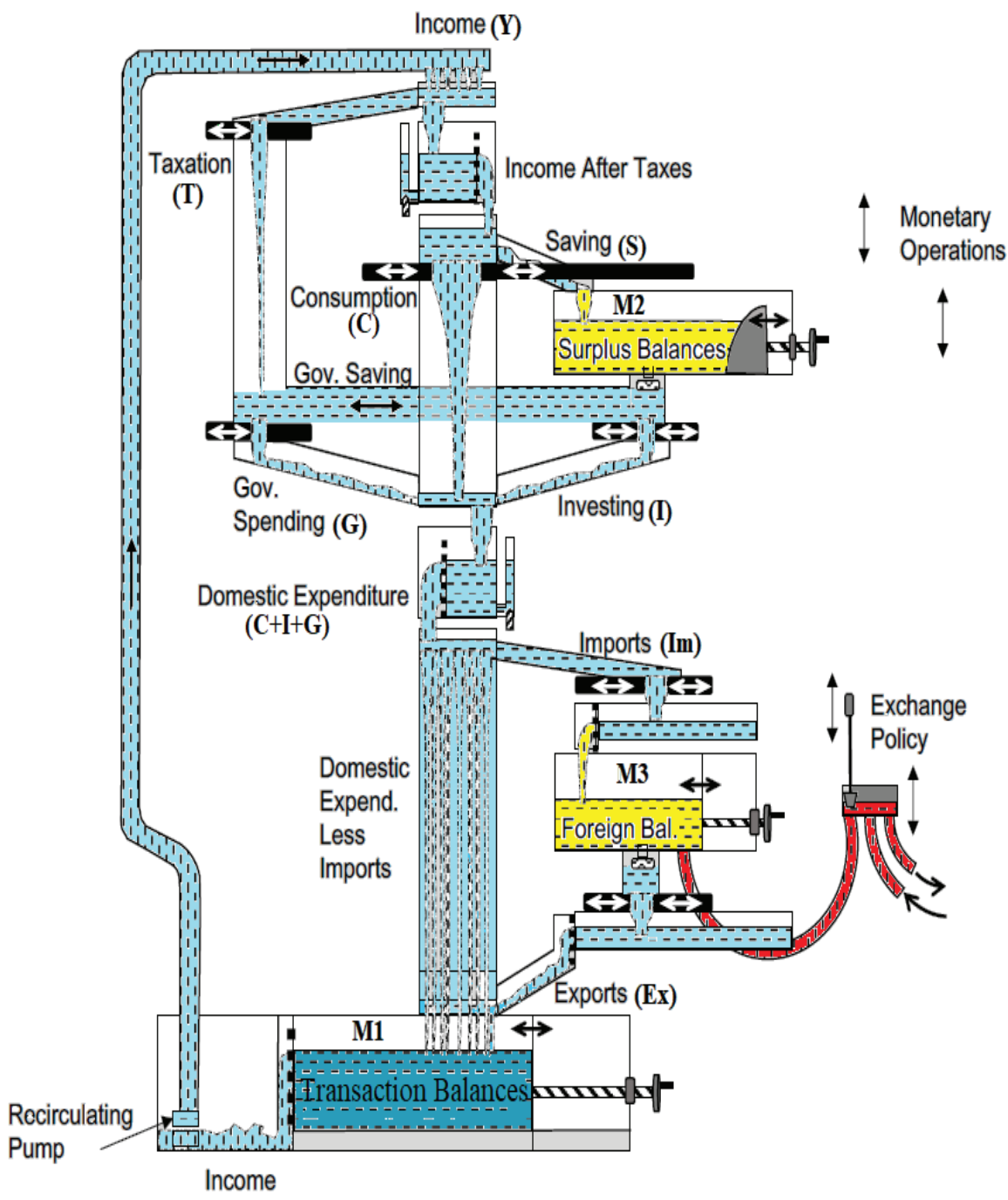

Source: Ryder, W.H. \& Cavana, R. Y. (2017)

The operation mechanism of the MONIAC machine is shown in Figure 2. The water pumped through the pipes after the machine is started is considered as cash entering the economy and constitutes the income of economic units. In this way, there is national income flow at the bottom and savings and investment flow at the top. The income $(Y)$ is primarily taxed by the state $(T)$. The tax is a resource 
for the public to meet its expenditures and is transferred to public expenditures $(G)$. On the other hand, the remaining income after tax (IAT) is used as consumption (C) and savings (S). The machine also shows how much of the IAT will be spent on consumption. This distinction varies depending on the size of IAT and interest rates.

The saving part of the disposable income is collected in the M2 tank, which constitutes idle funds. The M2 tank also shows the money stock held for speculative purposes and refers to the amount of money stock to be held for this purpose instead of bonds, namely the liquidity preference. The amount that will go to the savings channel is influenced by two variables, and this is indicated by two opposing valves on the machine that determine the amount of water directed towards the savings channel. One of them is interest rates and the other is the amount of the IAT. The valve on the left refers to savings that vary with income level, that is, to express the marginal propensity to save. When this valve shifts to the right, the marginal propensity to save decreases, and the amount of water (income level) that will go to the savings channel decreases. Conversely, when the valve moves to the left, the flow into the savings channel increases, indicating that the marginal propensity to save increases. The second valve, which determines the amount of water that will go to the savings channel, is located on the right side of the channel, and moves to the right or left according to the change in interest rates. When interest rates fall, this valve moves to the right and the gap between the two valves opens, reducing the flow to the savings channel. On the contrary, the valve's movement to the left with an increase in interest rates shows that the interest elasticity of savings will increase, and savings will also increase. Consumption, on the other hand, will act opposite to saving, and the mutual valves will affect the consumption expenditures by reflecting the change in income and interest rates.

The loanable funds theory and Keynes's original theory can be taken as a reference to monitor the determination of the interest rates in the machine. We observe the first effect of the changing amount of savings with the effect of the interest rate and income variables represented by the valves as the water flows 
through the savings channel, filling the tank at the top right, M2. As this tank fills up, that is, as the savings increase (supply of loanable funds), the interest rate decreases, and more resources are transferred to the investment tank with the opening of the corresponding metal extension, i.e. the investment expenditure (I) increases. The interest rate can also change with an external intervention. There is a valve that allows us to take or drain water into this tank. In this way, we can see the effects of the central bank supplying and withdrawing money from the economy. If the central bank increases the money supply in the economy, the interest rates decrease; on the contrary, if it goes to monetary tightening, the interest rates increase.

The machine was also designed to show the part of investment expenditures depending on the income. Of the two mutual metal extensions that determine the investments, the extension on the right represents the interest rates while the left one reflects the effect of income-induced changes in investments. In this sense, the hydraulic machine includes the accelerating mechanism. Therefore, when there is a change in the system, investment expenditures will react with a delay to the change in income. In this way, investment expenditures, which arise depending on the interest rates and income level, are combined with the continuing consumption and public expenditures in the economy, forming domestic expenditures, $\mathrm{C}+\mathrm{I}+\mathrm{C}$.

A part of the income generated in this way is transferred to the rest of the world, that is, it is allocated for expenditures on imports ( $\mathrm{Im})$. The part allocated to imports changes depending on both income level and exchange rates. Import fills the bottom right tank, M3 tank, which shows the part of the national income held by the rest of the world and forms the money stock (foreign-owned balances) held by other countries through import. The income of the rest of the world generated by their exports is partly spent on the other countries' goods and services, forming exports (Ex), which return to the circular flow of income as a contribution. Just as the water level in the M2 tank determines the interest rates, this time the water level in the M3 tank determines the exchange rates. Thus, the rate of change of imports and exports determines the exchange rates, and imports and exports react to changes in exchange rates. Thus, $Y=C+I+C+(E x-I m)$ 
creates the active balances of the economy and it re-enters the economy as income and restarts the cycle.

The machine has the features that can simultaneously solve the relevant equations and move the system to a new equilibrium when one of the total demand components changes. Thus, it has made it easier to follow the effects of economic policies on the economy and to comprehend different economic theories. Phillips conceived of the machine as the result of an effort to develop a mechanical model that would enable non-mathematicians to understand numerical changes in the system of interrelated variables caused by changes in one or more of them. Assuming that the machine works with $+/-4 \%$ accuracy, Phillips argued that it is not a precise computational tool that can solve differential equations, but a tool that visualizes the motions of these variables and their relationships with each other within an equilibrium system. (Phillips, 1950, p. 284). However, its main function is seen as helping to comprehend the dynamics of complex principles and the functioning of the economy.

\subsection{MONIAC as a Training Tool and Simulation of the Machine}

Although the use of mathematical models in economics can be traced back to the second half of the 1800s, when the marginalist school was effective, the use of differential equations has increased rapidly since the 1950s. However, excessive use of mathematical models in economics has always been a controversial topic. One of the most important reasons for this is that economics students whose field of study is not mathematics have difficulty in using these models and in establishing their connection with economic facts. In this sense, mechanical models explaining economic facts and processes gained importance, and it came to the fore to design machines that can easily understand differential equations and quantitative changes occurring in the system of independent variables. MONIAC, invented by Phillips, is one of these initiatives (Phillips, 1950, p. 283).

The machine that visualizes the flow of money in the economic system appears to be extremely useful as an educational tool, given the complexity of the model under 
study (Barr, 2000). During the period when the machine attracted attention as an educational tool, there were requests from various universities, public institutions, and central banks to have it in their inventories. In this context, it is known that MONIAC was used as an educational tool in 1953 by the Nobel Prize-winning Economist Professor James Meade in the lectures he gave at LSE. In addition, Professor Wilfred Prest, who went to LSE for education in 1953, requested to bring the machine to the Department

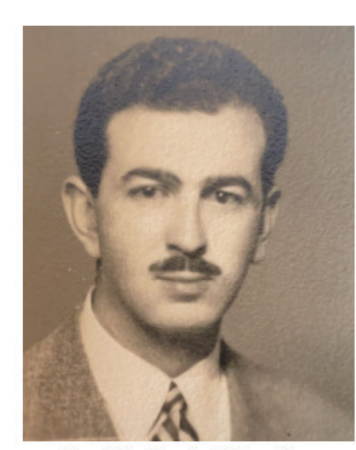

Prof. Dr. Besim Üstünel of Economics at Melbourne University and used it in his classes (Corkhill, 2012). Similarly, in 1954, Istanbul University faculty member Prof. Dr. Besim Üstünel brought the machine to Istanbul University Faculty of Economics. He used the machine as a course material in his lessons during his years as a lecturer at the university.

As of today, it is known that there is a total of 14 MONIACs in different versions around the world, including the London Science Museum, the University of Leeds, the University of Cambridge, the University of Rotterdam, the University of Melbourne, the Central Bank of New Zealand, and one of them is in the Faculty of Economics of Istanbul University (Silverstone, 2012). Today, although digital computers can perform the calculation function quite quickly, MONIAC continues to be attractive as the only visual model of its kind (Barr, 2000).

With the rapid advancement in technology, digital learning-teaching tools started to be used functionally in education. However, MONIAC, which visually reflects the macroeconomic system, is important for Istanbul University Faculty of Economics in terms of its historical meaning and scientific value. In this context, as an output of the project supported by the Scientific Research Projects Unit of Istanbul University, a simulation was prepared to be used in the lessons, taking into account the working principles of MONIAC. 
Figure 3. MONIAC Simulation

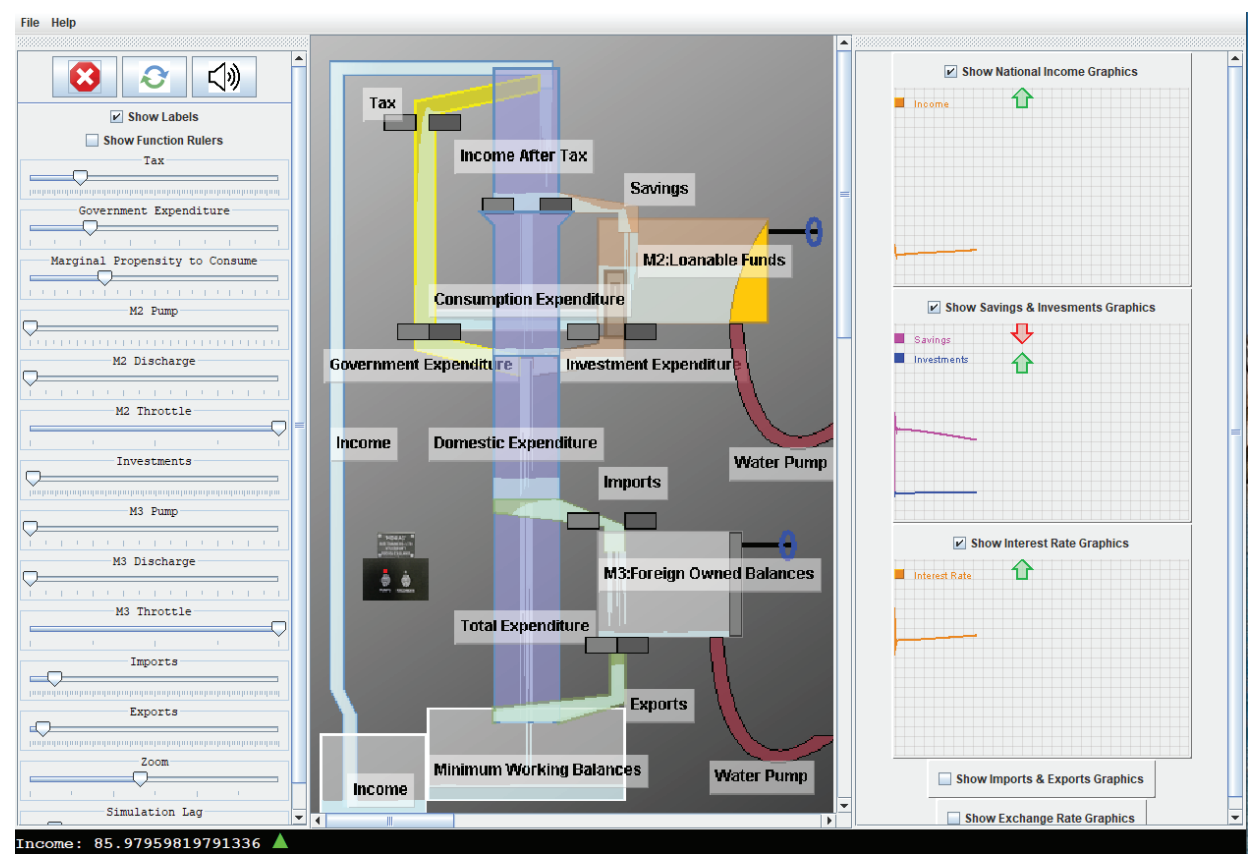

Figure 3 shows the interface of this program. It can be seen from the Figure that in the interface developed considering the physical appearance of the MONIAC, water flows representing the movement of economic variables can be monitored through transparent tubes.

Through this program, the quantitative relationships between input and output indicators in the context of MONIAC working principles are presented visually and used as a training tool in economics lessons.

\section{Conclusion}

The contribution of MONIAC to economics is to provide a visual understanding of theoretical economic models and to show us concretely how the elements of national income change and determine the size of the national income. In this respect, the machine should be seen as an important development in making a combination of mechanization and economics. The machine in the Faculty of Economics is one of the 
four machines currently in operation in the world. The Faculty sees the machine as a step for the use of new educational technologies in economics education and supports the development of new projects for the adaptation of these technologies. However, the use of such analog machines is limited. Today, developing digital and virtual technologies enable us to adapt digital learning-teaching tools to the education environment. For this reason, we aimed to make a simulation of the analog machine and reuse the machine for digital training purposes. In addition to the historical and scientific value of MONIAC for the Faculty, it also pioneers our goal of benefiting from these technologies, producing different digital educational materials and using them in lectures at the Faculty of Economics.

Peer-review: Externally peer-reviewed.

Conflict of Interest: The authors have no conflict of interest to declare.

Grant Support: This study was funded by the Scientific Research Projects Coordination Unit of Istanbul University. Project number SBA-2018-29155.

Hakem Değerlendirmesi: Dış bağımsız.

Çıkar Çatışması: Yazarlar çıkar çatışması bildirmemiştir.

Finansal Destek: Bu çalışma İstanbul Üniversitesi Bilimsel Araştırma Projeleri Koordinasyon Birimi tarafindan desteklenmektedir. Proje numarası SBA-2018-29155'tir.

\section{References/Kaynaklar}

Barr, N. (2000). The History of the Phillips Machine. In R. Leeson (Ed.), A.W.H Phillips: Collected Works in Contemporary Perspective, pp.89-114, Cambridge, UK: Cambridge Univ. Press.

Bollard, A. E. (2011). Man, Money, and Machines: The Contributions of A. W. Phillips. Economica, 78 (309), 1-9.

Corkhill, A. (2012). A Superb Explanatory Device: The MONIAC, an Early Hydraulic Analog Computer. University of Melbourne Collections, 10, 24-28.

Ng. T. \& Wright. M. (2007). Introducing the MONIAC: an early and innovative economic model. The Reserve Bank of New Zealand Bulletin, 70 (4), 46-52

NZIER (2016). The Moniac machine is a dynamic model of a working economy. New Zealand Institute of Economics Research, Wellington, New Zealand. Available at http://nzier.org.nz/about/monia-

Phillips, A. W. (1950). Mechanical Models in Economic Dynamics. Economica, 17 (67), 285-305.

Ryder, W. H. \& Cavana, R. Y. (2017). A System Dynamics View of the Phillips Machine: "Chasing some Hares!". 2nd Paper presented at the Asia-Pacific Region System Dynamics Conference of the System Dynamics Society, February 19-22, National University of Singapore, Singapore.

Silverstone, B. (2012). MONIAC: Phillips Monetary National Income Analogue Computing Machine. Special Issue of Economia Politica, December 2011 Edited by K. Vela Velupillai. Journal of Economic Surveys, 26, 968-970. https://doi.org/10.1111/j.1467-6419.2012.00736.x 


\section{Restoration Process of MONIAC at the Faculty of Economics}

MONIAC was brought to Istanbul University Faculty of Economics shortly after its invention with the efforts of Prof. Besim Üstünel, who went to study at LSE and was introduced to the machine there, and the support of Refik Şükrü Suvla who was the dean of that period. The machine was used as a training material in undergraduate and graduate courses. After the departure of Professor Üstünel from the faculty in 1959, the machine was not used anymore, and it was removed to the faculty warehouses.

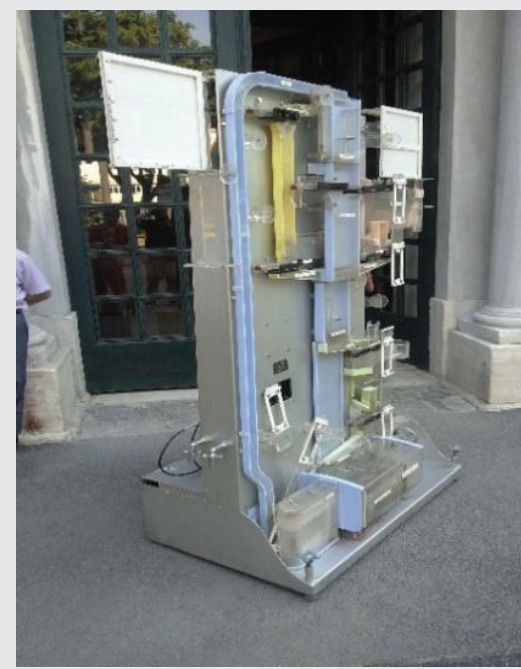

In 2017, the dean of the faculty of economics, Prof. Dr. Haluk Alkan, started a project with the sponsorship of Türkiye Iş Bankası and the support of the Istanbul University to make the machine rework.

In 2017, the original machine was delivered to Expert Physicist Adem Soylamış, who is working in the Physics Department of Istanbul University Faculty of Science. The original drawing of the machine, consisting of 110 pages and 1400 parts, was made before the repair of the machine, which was taken to the laboratory of the Physics Department of Istanbul University and then the whole machine was divided into parts.

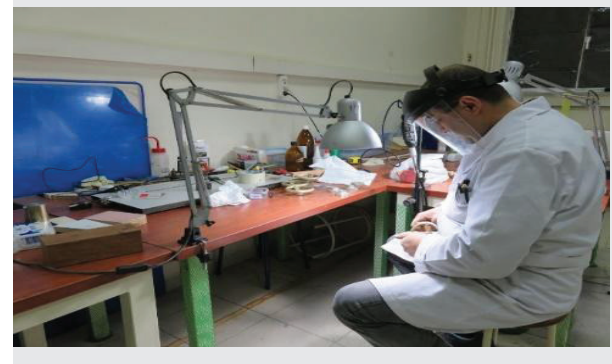

All parts were revised by the expert physicist Soylamıs. Replacing the broken parts, new parts that are the same as the original ones were produced, and the missing parts were rebuilt by examining the MONIAC video in New Zealand, 
which was in operation. The assembly of the machine, which was divided into 1400 parts in a short period of six months, was completed and the machine was made operational again in 2018. The machine is currently displayed on the administration floor of Istanbul

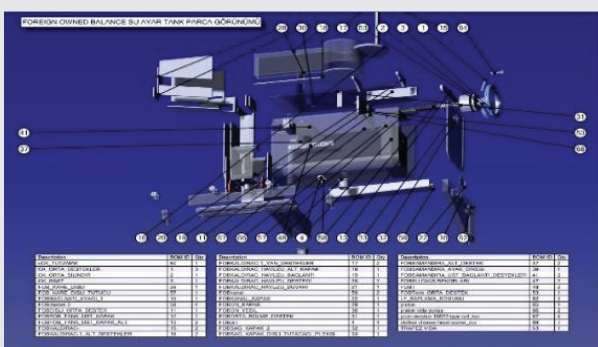
University Faculty of Economics.
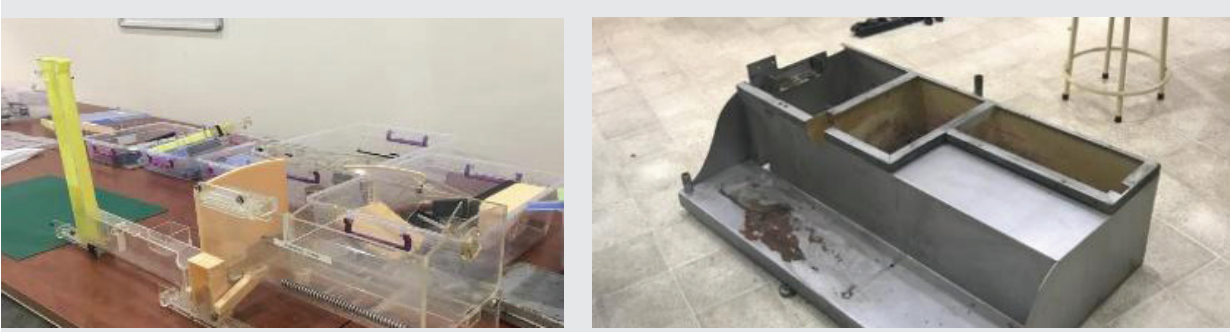


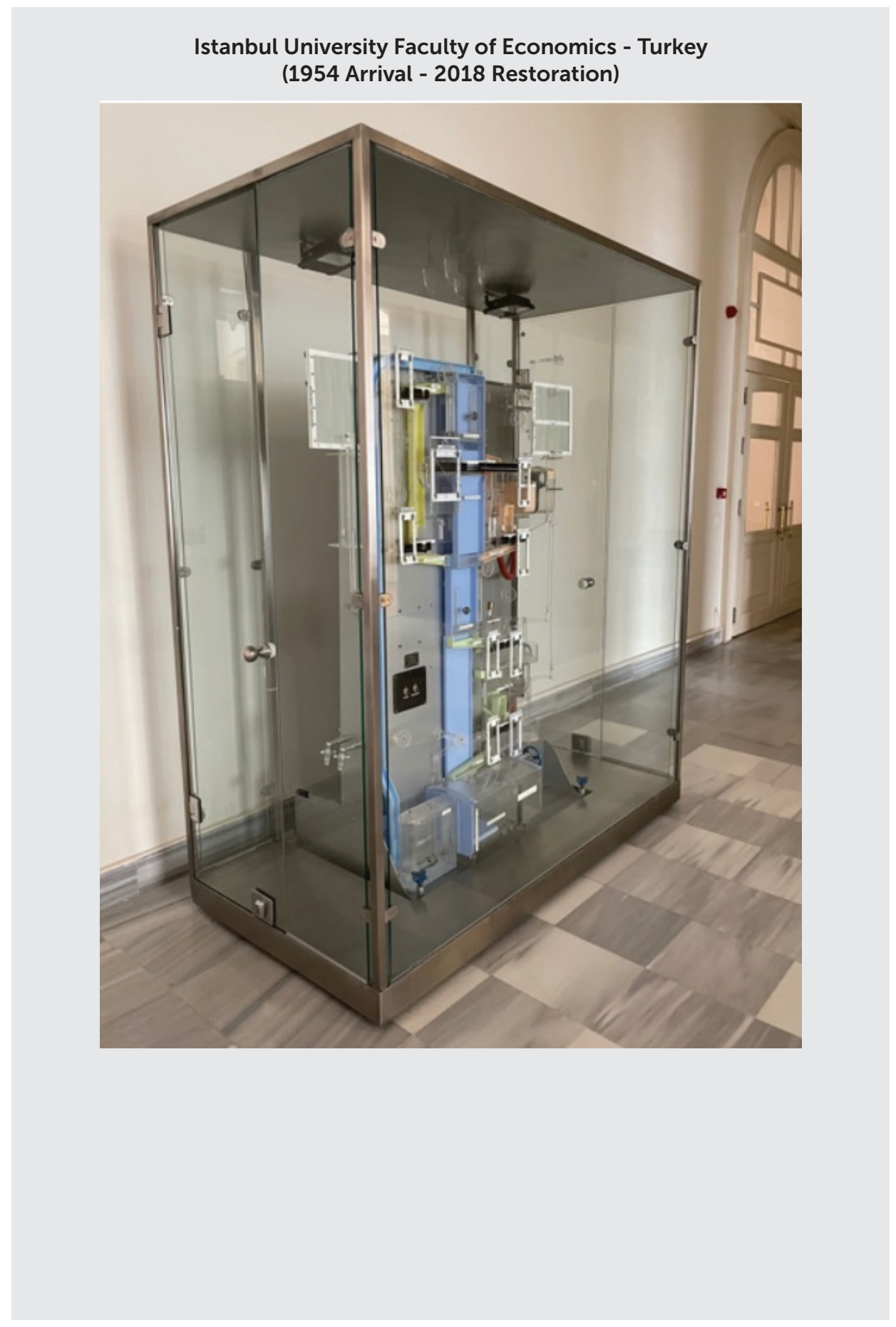


